\title{
Non-Linear Behavior of Unbonded Post-Tensioned one-way Concrete Slab Panel
}

\author{
Jamal S. Abdulamier ${ }^{2}$, Ali H. Aziz ${ }^{2}$ and Haider S. Al-aasam ${ }^{1}$ \\ ${ }^{1}$ Postgraduate Student. \\ ${ }^{2}$ Supervisors, Civil Eng. Department/Al-Mustansriya University/Iraq.
}

Rec. 6 Jan, 2012, Accpt. 27 Feb, 2012

\begin{abstract}
In this research, a nonlinear finite element model developed to investigate the behavior and ultimate load capacity of unbonded post-tensioned one-way concrete slab panel. The numerical treatment adopted by finite element ANSYS software has been carried out on two different one-way concrete slabs chosen from previous available experimental study in order to evaluate their results. Mode of failure and the loaddeflection relationship are presented for two cases. A parametric study was conducted to study the effects on the global structural behavior due to the effect of concrete compressive strength, effect of effective prestressing stress, effect of prestressing (post-tensioning) technique, types of loading, effect of tendon profile, effect of tendon bonding, effect of span to depth ratio of concrete slabs.
\end{abstract}

Keywords:Post-Tension, Concrete, Slab, Finite Element, ANSYS

\section{Introduction}

Post-tensioning of concrete slabs can be constructed using unbonded or bonded tendons. For unbonded slabs the transfer of force from the tendons to the concrete is via the end anchors, with strains in the tendons distributed throughout their entire length, and also via the profile of the tendons. Friction forces between the tendon and concrete are very small since the tendon is typically greased and housed within a plastic tube (duct). In bonded slabs the transfer of the force is via the end anchors, together with the bond between the tendons and concrete (after grouting), and via the curvature of the tendons. Compared to bonded systems, unbonded post-tensioned concrete slabs are more economic, easier to construct and have the possibility to replace or repair any defective tendons. However, they are not considered to be as robust as bonded systems.

The behavior of post-tensioned concrete structural members has previously been investigated experimentally by (Brotchie, 1980; Williams and Waldron, 1989;Schupack, 1991; Tan and $\mathrm{Ng}$, 1997; Chen and Wissawapaisal, 2001; Chakrabarti, 2005). and a number of other researchers. A detailed review of various studies can be found in (Khan and Williams, 1995 and Ellobody and Bailey).
Numerical and theoretical models have been previously developed by other researchers to study the behavior of unbondedprestressed concrete members. (Alkairi and Naaman).developed an analytical model to study the behavior of unbonded tendons in simply-supported symmetrical beams. The model was simplified since the interaction between the tendon and concrete, unsymmetrical loading, post-cracking tensile capacity and time effects were all ignored in the analysis. In (Moon and Burns, 1997).analytical method for unbondedprestressed members, the geometrical changes in the tendon profile during the deformation of the member were ignored. (Wu et al.,2001).presented a numerical procedure for the analysis of prestressed concrete structures. However, there was no experimental investigation included within this research and the calculation of prestress losses relied on equations presented in current codes of practice. Based on the review of previous research, summarized above, it was found that an efficient 3-D finite element model with nonlinear material models for the tendon and concrete is needed to accurately study the behavior of unbonded post-tensioned concrete slabs. The proposed model must also include the correct transfer of force between the tendon and concrete at the anchor points and

\footnotetext{
Corresponding author:

Mr. Haider S. Al-aasam

$\varangle$ haider.sa@gmail.com
} 
ensure that the tendon retains its correct geometry during the deformation of the slab.

This research presents a finite element model, using ANSYS software (Ver. 12.0). (withoutcivilFEM) To validate the model two unbonded post-tensioned concrete slabs have been chosen from the previous available experimental study tested by (Ellobody and Bailey). A parametric study is also presented investigating the effect of concrete compressive strength effective prestressing stress, prestressing (post-tensioning) technique, types of loading, tendon profile, tendon bonding and span to depth on the behavior of unbonded post-tensioned concrete slabs.

\section{Experimental Tests:}

Two unbonded post-tensioned concrete slabs have been chosen from the available experimental study for the numerical analyses. The slabs, designated as (T1) with $\left(f_{c}^{\prime}=44.4 \mathrm{MPa}\right)$ and (T2) with $\left(f^{\prime}{ }_{c}=48.2 \mathrm{MPa}\right)$, where a simply supported subjected to four concentrated point loads and tested by (Ellobody and Bailey). The unbonded post-tensioned slabs were designed according to BS8110-1 (2002). The general layout of the unbonded post-tensioned one-way concrete slab is shown in Figure (1).

The overall dimensions of the slabs are with an overall length of $4300 \mathrm{~mm}$, a span of $(4000 \mathrm{~mm})$, a width of $(1600 \mathrm{~mm})$, and a depth of $(160 \mathrm{~mm})$. Apart from the bursting reinforcement, there was no other conventional (passive) reinforcement included in the slabs.

The slabs was positioned in the loading frame as shown in Figure (2). The jacking load was applied at regular intervals of $(5 \mathrm{kN})$. Initially, both slabs (T1) and (T2) behaved linearly and the observed deflections were small up to $(42.4 \mathrm{kN})$. Moreover, The slabs was supported on two (356 $\times$ $171 \times 67 \mathrm{~mm})$ I-Section steel beams and loaded at four locations using spreader plates $(1600 \times 350 \times$ $40 \mathrm{~mm})$.



Figure (1). General Layout of the Post-tensioned Slabs T1 \& T2.

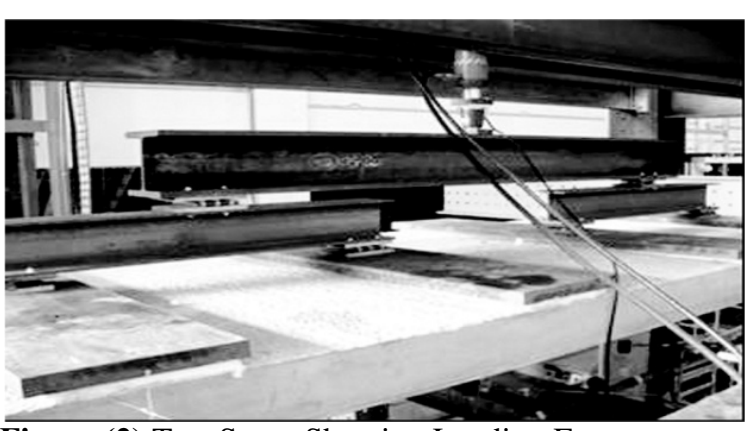

Figure (2).Test Setup Showing Loading Frame.

\section{Modeling of Material Properties:}

Concrete exhibits a complex structural response with various important nonlinearities namely, the nonlinear stress-strain behavior, tensile cracking, compression crushing, in addition to time- dependent effects such as creep, shrinkage and temperature change, which all contribute to the nonlinear response. All these nonlinearities depends strongly on the triaxial state of stress.

Concrete was modeled using the plasticity based model implemented in the ANSYS. The model provides a general capability for modeling plain and reinforced concrete in all types of structures. The plasticity theory provides a mathematical relationship that characterizes the elasto- plastic response of materials, in combination with isotropic tensile and 
compressive plasticity, to represent the inelastic behavior of concrete. The model assumes that the uniaxial tensile and compressive response of concrete is characterized by plasticity based model. Under uniaxial compression the response is linear until the value of proportional limit stress, $\left(f_{c o}\right)$ is reached which is assumed to equal 0.30 times the compressive strength $\left(f_{c}\right)$. Under uniaxial tension the stress-strain curve $\mathrm{s}$ assumed to be linearly elastic up to the ultimate tensile strength. After this point, the concrete cracks and the strength decreases to zero. Figure (3) shows the Simplified Uniaxial Stress-Strain relationship that is used in this study.

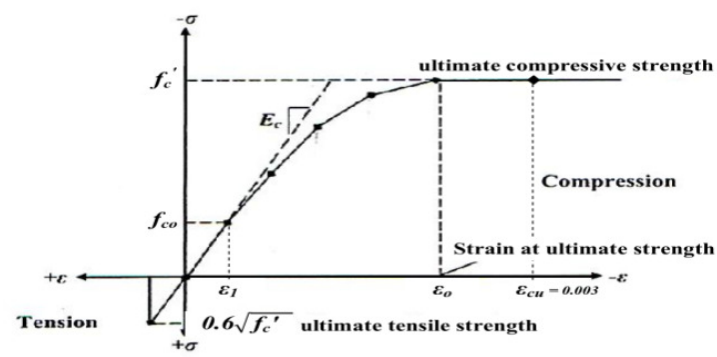

Figure (3). Simplified Uniaxial Stress-Strain Curve For Concrete

\section{ANSYS Finite Element Model:}

By taking the advantage of the symmetry of both slab's geometry and loading, a quarter of the entire model slab is used for the finite element analysis. The aim of this was to reduce the computational time.

\section{Finite Element Model of Concrete:}

In the present study, 3-D brick element with 8nodes was used to model the concrete (SOLID65 in ANSYS). The element has eight corner nodes, and each node has three degrees of freedom ( $\mathbf{u}, \mathbf{v}$ and winx, $\mathbf{y}$ and $\mathbf{z}$ direction respectively). The element is capable of plastic deformation, cracking in three orthogonal directions, and crushing. The geometry and node locations for this element type are shown in Figure (4).

\section{Finite Element Model of Steel Plates:}

In the finite element method, each load is distributed over a small area as $n$ the experimental slab specimens. Steel plates were added at the support locations and under the point load (applied load) in order to avoid stress concentration problems. This provided a more even stress distribution over the load and support area. Solid element (SOLID45 in ANSYS) was used for the steel plates. The element is defined with eight nodes having three degrees of freedom at each node; translations in $\mathrm{x}, \mathrm{y}$ and directions, Figure (4).

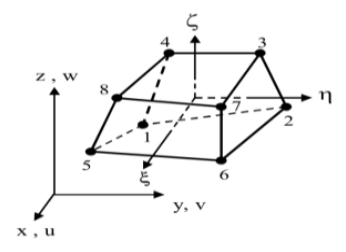

General 8-node Brick Elemen



b) 8-node Brick Element in Local
Coordinate System
Figure (4).Three Dimensional 8-node Brick Element.

Finite Element Model of Prestressing and NonPrestressing Reinforcement:

In the present study, the prestressing and nonprestressing reinforcements (tensile, compressive, tendon and bursting reinforcement) were represented by using 2-node discrete representation (LINK8 in ANSYS) and included within the properties of 8-node brick elements. The link element is assumed to be capable of transmitting axial forces only, and perfect bond is assumed to exist between the concrete and the reinforcing bars.Toprovide the perfectbond, the link element for the steel reinforcing bar was connected between nodes of each adjacent concrete solid element, so the two materials share the same nodes.

For tendon cable, since it is located inside the concrete section (throw the hole) and the prestressing force is transferred to concrete through end anchorages and profile of tendon, the cable is connected to slab only at the anchorages (ends).

\section{Finite Element Model of Interface:}

The contact between the concrete and the tendon was modeled by contact elements (using the CONTACT PAIR MANEGER) available within the ANSYS program element library. The method requires defining two surfaces that are the target and contact surface. The target surface within this model (TARGE170 in ANSYS) represents rigid surface is defined as the concrete surface surrounding the tendon and the contact surface (CONTA175 in ANSYS) represents contact, slid and deformable surface is defined as the tendon surface. The contact elements has four corner nodes, and each node has three translation degrees of freedom $(\mathrm{u}, \mathrm{v}$ and $\mathrm{w})$ in $\mathrm{x}, \mathrm{y}$ and $\mathrm{z}$ 
directions respectively. This element is located on the surface of 3-D solid (such as 8-node brick element) and has the same geometric characteristics as the solid element face with which it is connected. The contact elements are formed using these two surfaces and monitors the displacement of the contact surface in relation to the target surface. The contact details is shown in Fig. (5).

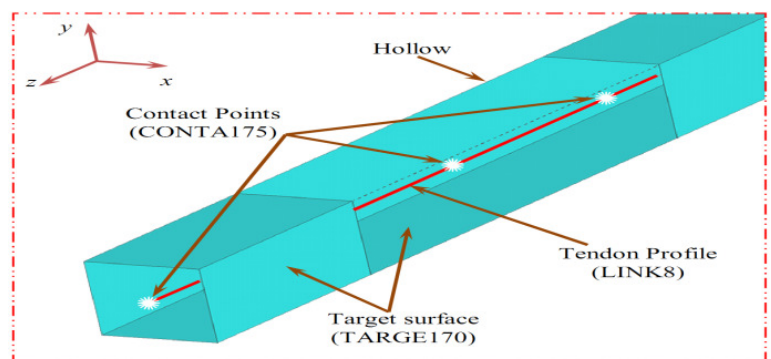

Figure (5). Contact Elements (Interface)

The finite element analysis has been carried out in general using 8 -point $(2 \times 2 \times 2)$ integration rule for the reinforced concrete brick elements and 4-point $(2 \times 2)$ integration rule for the steel plates elements and for the interface elements, with a convergence tolerance of $0.1 \%$. The full NewtonRaphson method has been adopted in the analysis; all mesh details are shown in Fig.(6) and Fig.(7).

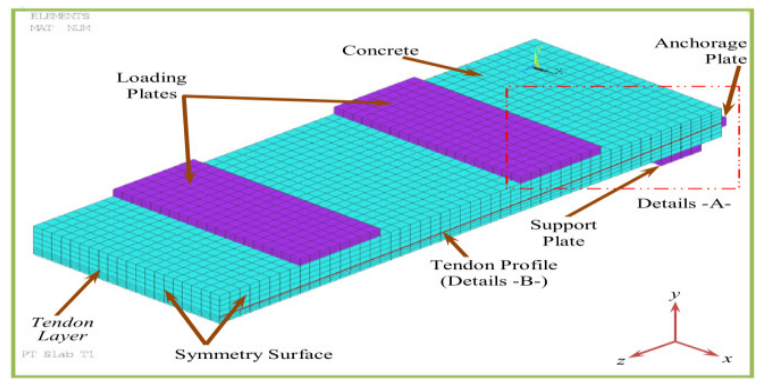

Figure (6). Finite Element Mesh for Quarter of The Slab.

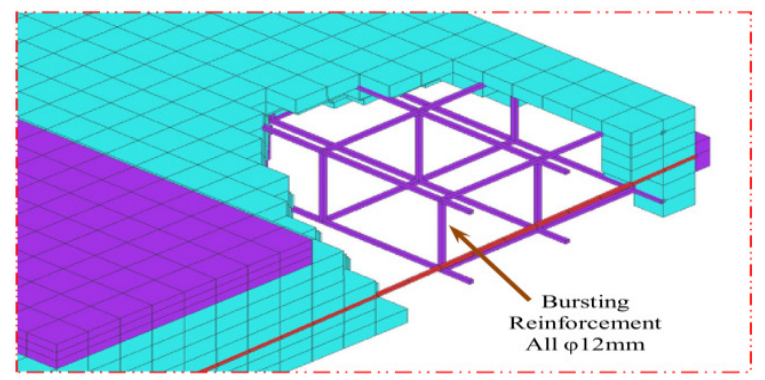

Figure (7). Details -A- Bursting Reinforcement Location (at ends)

\section{Verification of Finite Element Model:}

The results from the ANSYS (12.0) finite element analyses were compared with the experimental data. The following comparisons are made: load-deflection curves at midspan; first cracking load; load at failure. Also, discuss the development of crack patterns for slab (T1)and slab(T2). The experimental and numerical loaddeflection curves obtained for slab (T1) and slab (T2) are shown in Figures (8) and (9) respectively.

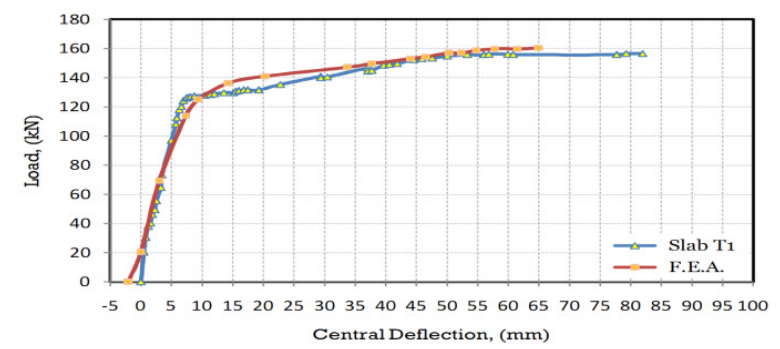

Figure (8). Load- Deflection Curve for Slab (T1).

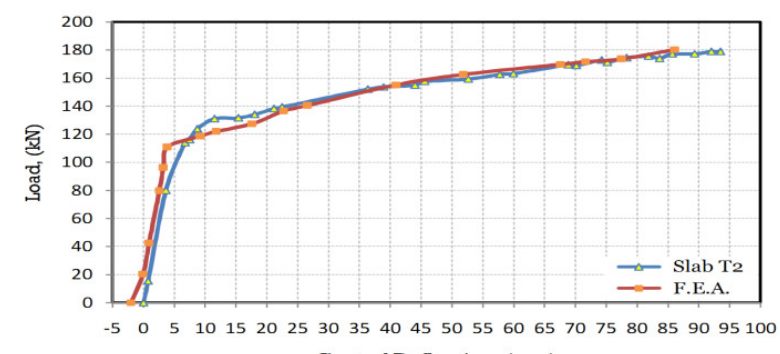

Figure (9). Load- Deflection Curve for Slab (T2).

Good agreement is in load-deflection relation prior to cracking load after the appearance of flexural cracks. At ultimate state, the numerical load is slightly larger than experimental load, and a relatively stiffener response has been obtained in the post cracking stage of behavior for slabs.

For slab (T1), the failure load from experimental was $(156.6 \mathrm{kN})$, at a central deflection of $(81.9 \mathrm{~mm})$, compared to $(160.7 \mathrm{kN})$ and $(65.67$ $\mathrm{mm}$ ) obtained from the model. The failure load predicted using the model was $(2.6 \%)$ higher than that observed from the test. The mode of failure is Concrete Crushing (CC) in the model corresponded to the mode of failure in experimental. The first flexural cracking initiates at $62.5 \%$ from the ultimate load. The first crack observed in tension zone of the slab as shown in Figure (10) and extend towards top face of slab in compression zone. Figure (11) also show crack 
pattern at ultimate state.

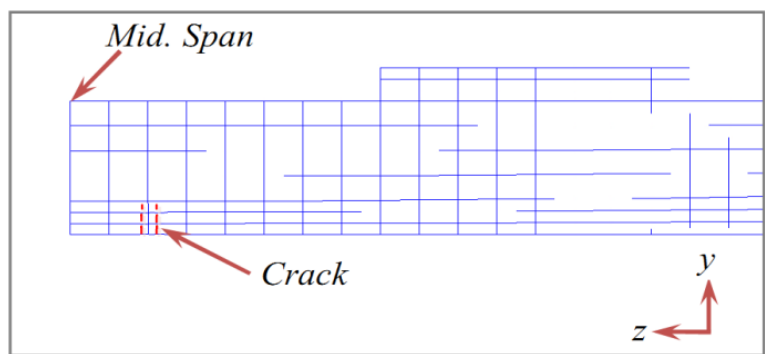

Figure (10).The First Crack at $62.5 \%$ of Ultimate Load

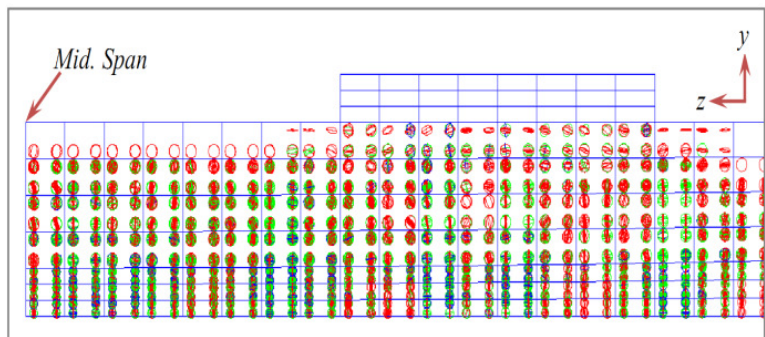

Figure (11). Crack Pattern Near Mid-span at Load = $160.7 \mathrm{kN}$

For slab (T2), the failure load from experimental was $(178.2 \mathrm{kN})$, at a central deflection of $(93.5$ $\mathrm{mm})$, compared to $(180.4 \mathrm{kN})$ and $(86 \mathrm{~mm})$ obtained from the model. The failure load predicted using the model was (1.23\%) higher than that observed from the test. The stress contours within the concrete elements are shown in Figure (12). The maximum compressive strains at failure occurred in the top concrete layer under the middle spreader plate (off-set from the mid-span) as observed in the test, with concrete crushing (CC) predicted. The strain of the tendons recorded from the finite element model was exceeding the measured yield strain, therefore the mode of failure is Tendon Yielding (TY).

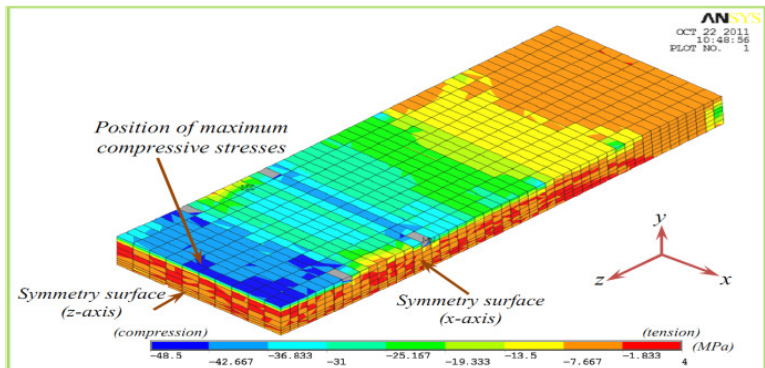

Figure (12). Stresses Distribution for Concrete at Failure Load for Slab (T2).

Parametric Study:

The verified finite element model was used to investigate the effect of several selected parameters on the overall behavior of posttensioned one-way concrete slab. These parameters include the effect of concrete compressive strength, effect of effective prestressing stress, effect of prestressing (posttensioning) technique, types of loading, effect of tendon profile, effect of tendon bonding, effect of span to depth ratio of concrete slabs. It has been found that, as the compressive strength of concrete increases from (40 MPa) to $(70 \mathrm{MPa})$ the ultimate load increases by about $(43.77 \%)$ and for higher value of ratio $\left(f_{p e} / f_{p u}\right)$ (effective prestress to ultimate stress) the ultimate load increases. The ultimate load for post-tensioned concrete slab increase approximately $(66.8 \%)$ more than the same slab without prestressing (ordinary reinforcement slab). The increase in the ultimate load of the slab subjected to four point load is $(20.7 \%)$ larger than that of the slab with a single load at mid-span. It is noted that the ultimate capacity increases when curved tendon profile is used. Also it is noted that the slab with full bonded more stiff than the same slab with full or partial unbonded.

Important effect has been noted by increasing the ratio of the span to thickness of concrete slab $(l / t)$ from (20) to (45) lead to an decrease in the ultimate load by about (10.8\%).

\section{Conclusions:}

Based on the finite element method by using ANSYS computer program (version 12.0), the analysis with a numerical results is described in previous section, it can be concluded that the computational finite element models adopted in the current study are useful and adequate for analyzing an unbonded post-tensioned one-way concrete slab. The finite element model used in the present work is able to simulate the behavior of unbondedpost-tensioned one-way concrete slabs. The analytical tests carried out for the two cases studied indicated that the load -deflection response, ultimate loads behavior in concrete slab are in good agreement with the experimental results. This study investigates the effect of several factors on load-deflection response throughout the entire range of behavior using the nonlinear analysis by ANSYS computer program. Based on the previous factors, the following conclusions are obtained:- 
1. From the numerical analysis carried out to study the effect of compressive strength of concrete on the strength behavior, it was found that as the compressive strength of concrete is increased from $\left(40 \mathrm{~N} / \mathrm{mm}^{2}\right)$ to $\left(70 \mathrm{~N} / \mathrm{mm}^{2}\right)$ the ultimate load capacity is increased by about $(43.8 \%)$.

2. For different values of effective prestressing stress that are taken as $\left(f_{p e} / f_{p u}\right)$ ratio, the ultimate load is increased substantially by about $(8.1 \%)$ when the ratio is increased from $(0.25)$ to $(0.75)$. This can be attributed to increase in prestressing force that improves the stiffness of slab.

3. It was observed that the increase in the ultimate load capacity for unbonded post-tensioned slab by $(66.8 \%)$ is larger than the same slab without post-tensioned tendon.

4. The increased in ultimate load on the slab subjected to uniformly distributed load is $(35.1 \%)$ greater than that in beam with a single load at mid span.

5. It was found that the tendon profile has no significantly effect on the ultimate load capacity, where the results showed that ultimate load decreased $(5 \%)$ with straight tendon profile compared to curved tendon profile.

6. The finite element results obtained for the same slab assuming full and partial bond between tendon and concrete are shown that compared to a concrete slab with unbonded a stiffer behavior has been noticed. It was observed that the ultimate load capacity for slab with full bonded increase by $(4.9 \%)$ than the same slab with unbonded.

7. The strength of post-tensioned slabs are decreased by increasing the ratio of the depth to span of concrete slab $(\boldsymbol{l} / \boldsymbol{t})$, with keeping the width and depth of slabs constant and it was found that as the $(\boldsymbol{l} / \boldsymbol{t})$ ratio is increased from $(0.20)$ to $(0.45)$ the ultimate load decreases by about $(10.8 \%)$.

\section{References:}

Brotchie, J.F. (1980). "Experimental studies of prestressed thin plate structures",Adjournal, Vol. 77, No. 2, pp. 87-95.

Williams, M.S. and Waldron, P. (1989). "Movement of unbonded post-tensioning tendons during demolition", Proceedings of the Institution of Civil Engineers, Part 2, Vol. 87, pp. 225-253.

Schupack, M. (1991)."Evaluating buildings with unbonded tendons", Concrete International, Vol. 13, No. 10, pp. 52-57.

Tan, K. and Ng, C. (1997)."Effect of deviator and tendon configuration on behavior of externally prestressed beams", ACI Structural Journal, Vol. 94, No. 1, pp. 1322.

Chen, H.L. and Wissawapaisal, K. (2001). "Measurement of tensile forces in a sevenwire prestressing strand using stress waves", Journal of Engineering Mechanics, ASCE, Vol. 127, No. 6, pp. 599-606.

Chakrabarti, P.R. (2005). "Behavior of unbonded post-tensioned beams repaired and retrofitted with composite materials", Structures, ASCE Structures Congress, Metropolis and Beyond, N.Y., pp.1-11.

Khan, S. and Williams, M. (1995). "Posttensioned concrete floors". ButterworthHeinemann, Elsevier Science Ltd.

EhabEllobody and Colin G. Bailey, (2008). "Behavior of Unbonded Post-Tensioned One-way Concrete Slabs", Advances in Structural Engineering Vol.11 No.1, pp. 107-120.

Alkhairi, F.M. and Naaman, A.E. (1993). "Analysis of beams prestressed with unbonded internal and external tendons", Journal of Structural Engineering, ASCE, Vol. 119, No. 9, pp. 2680-2699.

Moon, J.H. and Burns, N.H. (1997). "Flexural behavior of member with unbonded tendons", Journal of Structural Engineering, ASCE, Vol. 123, No. 8, pp. 1087-1094.

Wu, X.H., Otani, S. and Shiohara, H. (2001). "Tendon model for nonlinear analysis of prestressed concrete structures", Journal of Structural Engineering, ASCE, Vol. 127, No. 4, pp. 398-405.

Zebun, M.A. (2006), "Behavior and Strength of Steel-Cincrete-Steel Sandwich Beams with Partial Shear Connection". Ph.D Thesis, University of Al-Mustansiriya. 
ANSYS, (2009). "ANSYS Help",Release 12.0, Copyright.

ACI Committee 318, (2008). "Building Code Requirements for Structural Concrete
(ACI 318M-08) and Commentary (ACI 318RM-08)", American Concrete Institute, Farmington Hills.

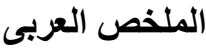

\section{السلوك اللاخطي لبلاطة خرسانية لاحقة الشد غير متلاصقة الاسلاك ذات الاتجاه الواحد}

\author{
جمال عبد الأمير'، علي عزيز"، حيدر صادق الأعسم'

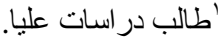 \\ 'المشرف (قسم الهندسة المدنية / كلية الهندسة / الجامعة المستتصرية).
}

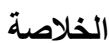

في هذا البحث، ثم تطوير نموذج مصمم بطريقة العناصر المحدد ثلاثي الأبعاد اللاخطي لدراسة السلوك وقدرة التحمل القصوى لبلاطة خرسانية لاحقة الثند غير متلاصقة الأسلاك ذات اتجاه واحد. ان التحليل العددي تم اعتماده بواسطة البرنامج الحاسوبي . ANSYS Ver)

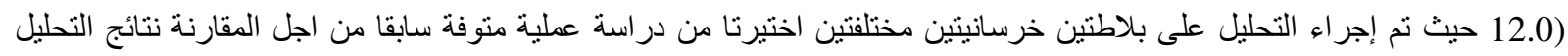

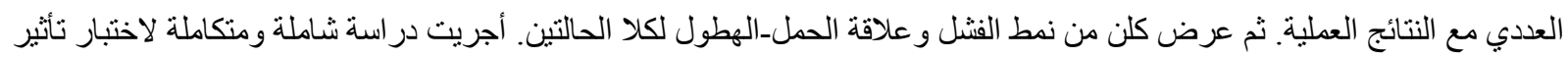
بضع عو امل مختارة على السلوك العام، هذه العو امل تتضمن تأثير مقاومة الانضغاط للخرسانة ونسبة الإجهاد المسبق الفعال إلىالإجهاد الفعلي ونأثير تقنية الإجهاد المسبق بأسلوب الثد اللاحق ذات الأسلاك الغير متلاصقة وتأثير توزيع الأحمال وطريقة مد السلك وشكله وتأثير التلاصق من عدمه بين السللك و الخرسانة ونسبة فضاء إلى عمق(سك) البلاطة الخرسانية. 